\title{
塩酸肺炎モデルにおけるインターロイキン-8 の経時的変化
}

$\begin{array}{lllllll}\text { 川前 } & \text { 金幸 } & \text { 田勢長一郎 } & \text { 村川 } & \text { 雅洋 } & \text { 大柣 } & \text { 学 } \\ \text { 松本 } & \text { 幸夫 } & \text { 島田 二郎 } & \text { 池上 } & \text { 之浩 } & \text { 五十洲 } & \text { 剛 }\end{array}$

\begin{abstract}
要約：好中球依存性肺障害の一つである燕下性肺炎の形成には, インターロイキン -8 (IL-8) が 重要な役割を担っている。抗IL-8療法の治療有効時間などを検討する根拠として, 塩酸肺炎モ デルを作成し, 肺組織, 気管肺洗浄液 (BALF), さらに血中のIL-8の経時的変化について検討 した。SD（Spraque-Dawley）系ラットを用い，塩酸（pH 1.5, $1.5 \mathrm{ml} \cdot \mathrm{kg}^{-1}$ ) を経気管的に投与 した。投与後経過観察時間を塩酸投与前，投与後 30 分， 1 時間， 2 時間， 3 時間， 4 時間とし， 各時間において, 無作為に 7 頭ずつ6 群について検討した。IL-8は, BALFおよび肺組織では 塩酸投与 1 時間目に有意の上昇を示し， 3 時間目に最高値となった。血中では 3 時間目に軽度上 昇し $\left(28.6 \pm 10 \mathrm{pg} \cdot \mathrm{m} l^{-1}\right), 4$ 時間目に有意 $\left(216 \pm 134 \mathrm{pg} \cdot \mathrm{m} l^{-1}\right)$ となった。塩酸注入後, BALF と肺組織の IL-8 は 3 時間後に最大となり，血中へは 4 時間後に有意に遊離した。
\end{abstract}

Key words: (1) interleukin-8, (2) aspiration pneumonia, (3) hydrochloric acid lung injury,

(4) cytokine

\section{はじめに}

外傷, 手術, 感染などの侵襲が生体に加わると, 局 所に炎症反応が生じる。侵襲が大きい場合, その影響 は局所にとどまらず，さまざまなサイトカインが血中 に出現して, 全身性の炎症を惹起し, 臟器不全へと進 展する11 4)。炎症性サイトカインの中でも，インター ロイキン-8（interleukin-8, IL-8）は標的臟器への炎症 細胞の集積をきたすことが知られており，好中球など の活性化により臟器障害が形成される。そこで, IL-8 をブロックして病態の悪化を軽減しょうとする試みが 動物実験などで行われており，極めて有効との報告が 多( 5), 6)。

Yokoi ら 5)は, エンドトキシンによる acute respiratory distress syndrome(ARDS) モデルにおいて，抗 IL-8抗体により肺障害がほぼ完全に予防されたことを 報告した。また, Folkesson ら6は，塩酸肺炎において 抗 IL-8抗体により肺損傷が予防され, また塩酸投与 1 時間後の治療でも炎症反応の軽減をみた。これらの結 果は, 肺損傷に対しIL-8が深くかかわっていることを 示唆すると同時に, 抗IL-8抗体の投与は臨床上有効で あろうとの期待を抱かせるものである。IL-8は多彩な
生物学的活性を有している腫痬壊死因子 - $a$ （tumor necrosis factor, TNF- $a$ ) やインターロイキン -1b （IL-1b）に比較して遅れて産生されるため, 治療開始 時期が多少遅れても臟器障害の進展を抑制できる可能 性がある。ARDSの原因として最も多く7)かつ予後も 極めて悪い誤嚥性肺炎のモデルを作成し, 肺内局所と 血中のIL-8の経時的変化から血中への移行について検 討し，抗 IL-8 抗体の投与時期について考察した。

\section{方 法}

Spraque-Dawley 系ラット（体重 $400 \pm 30 \mathrm{~g}, \mathrm{n}=56)$ を用い，麻酔はケタミン $\left(30 \mathrm{mg} \cdot \mathrm{kg}^{-1}\right)$, ザイラジン $(20$ $\left.\mathrm{mg} \cdot \mathrm{kg}^{-1}\right)$ を大腿部に筋注して行った。以後同薬を適宜 追加投与し, 必要に応じてパンクロニウム $\left(0.1 \mathrm{mg} \cdot \mathrm{kg}^{-1}\right)$ を静注した。気管切開, 頸動脈カニューレの挿入を行 い, 人工呼吸 (Rodent Ventilator Mod RV 4J, Canada）を行った。人工呼吸の設定条件は $\mathrm{FIO}_{2} 1.0$, PEEP $2 \mathrm{cmH}_{2} \mathrm{O}$, 一回換気量 $7 \mathrm{ml} \cdot \mathrm{kg}^{-1}$, 呼吸数 30 $35 \mathrm{~min}^{-1}$ とし, $\mathrm{PaCO}_{2}$ を $40 \mathrm{mmHg}$ 前後を保つように 呼吸数を調節した。

仰臥位とし， $\mathrm{pH} 1.5$ の $\mathrm{HCl} 1.5 \mathrm{ml} \cdot \mathrm{kg}^{-1}$ を気管内に 投与し，直後に $5 \mathrm{~m} l$ の空気を注入し20秒間のsqueezing 
を加えて肺内全体に拡散させて，重篤な塩酸肺炎モデ ルを作成した。その後, 無作為に, $\mathrm{FIO}_{2} 1.0$ で塩酸を 投与しない群 (control group 1: C1 群, $\mathrm{n}=7$ ), 初 めから室内空気 $\left(\mathrm{F}_{\mathrm{IO}} \mathrm{O}_{2} 0.2\right)$ で人工呼吸し塩酸を投与し ない群 (control group 2: $\mathrm{C} 2$ 群, $\mathrm{n}=7$ ), $\mathrm{FIO}_{2} 1.0$ で 人工呼吸し，塩酸の投与後も同条件で人工呼吸した群 (study group:S群， $\mathrm{n}=42$ ) の3つの群に分けた。S 群は心停止させる時間により,さらに6つの群に分け た。 $\mathrm{C} 1$ 群， C2 群は 4 時間で, S 群は各々 7 頭ずつ塩酸 投与前，投与 30 分後， 1 時間， 2 時間， 3 時間， 4 時間 でケタミン $250 \mathrm{mg} \cdot \mathrm{kg}^{-1}$ 静注にて心停止とし, 測定に 供した。

測定項目は，平均動脈圧（MAP）, 最高吸気気道内 圧 (PIP), そして, 動脈血中ガス分析 $\left(\mathrm{PaO}_{2}, \mathrm{PaCO}_{2}\right.$, $\mathrm{pH})$ で，塩酸注入前から経時的に 4 時間まで行った。 心停止後，心肺同時摘出し，右片肺に生理食塩水 $5 \mathrm{~m} l$ を注入，回収しbroncho-alveolar lavage fluid (BALF) とした。BALFは3回行った。その回収液BALFを 10 分間， $4^{\circ} \mathrm{C} ， 1,500$ 回転にて遠心後，上澄み液のIL-8を 測定した。一方，左片肺は液体窒素にて凍結， $-80^{\circ} \mathrm{C}$ にて保存後，肺組織のIL-8の測定に供した。組織中の IL-8はリン酸緩衝液を加えてホモジネートし，10分間， $4^{\circ} \mathrm{C} ， 3,000$ 回転にて遠心し，その後，上澄み液のIL-8を 測定すると同時に蛋白濃度を測定した。組織中のIL-8の 濃度は，IL-8の濃度を蛋白濃度で除して算出した。さ らに，動脈血液を遠心し，血清中の IL-8 も測定した。 IL-8の測定はELISA (Biosource 社製ELISA-KIT，CA) で行った。なお，今回測定したIL-8は，macrophage inflammatory protein-2（MIP-2）と呼ばれ，ラットに おいて好中球遊走活性化作用を有するものである ${ }^{8)}$

各デー夕はmean $\pm \mathrm{SD}$ で表示した。S群において塩 酸注入前值と各時間群との比較には $\mathrm{t}$ - 検定, C 群と $\mathrm{S}$ 群の比較には ANOVAを用いた。 S 群， C1 群，C2 群 の IL-8に関する 4 時間後の值の比較には MannWhitney のU- 検定を用いた。なお危険率 $P$ 值が 0.05 以下を有意差ありとした。

\section{結果}

1) MAP, PIP, $\mathrm{PaO}_{2}$ (Fig. 1)

a) 平均動脈圧 (MAP)

MAP は C1，C2 群で大きな変化はなかった。一方 S 群では, 塩酸注入前と比較し, 注入 30 分後有意に低下 した。しかし，2 時間目には有意に上昇し以後次第に 低下した。

b) 最高気道内圧（PIP）

PIP は C1，C2 群とも一定の值を保った。一方 S 群
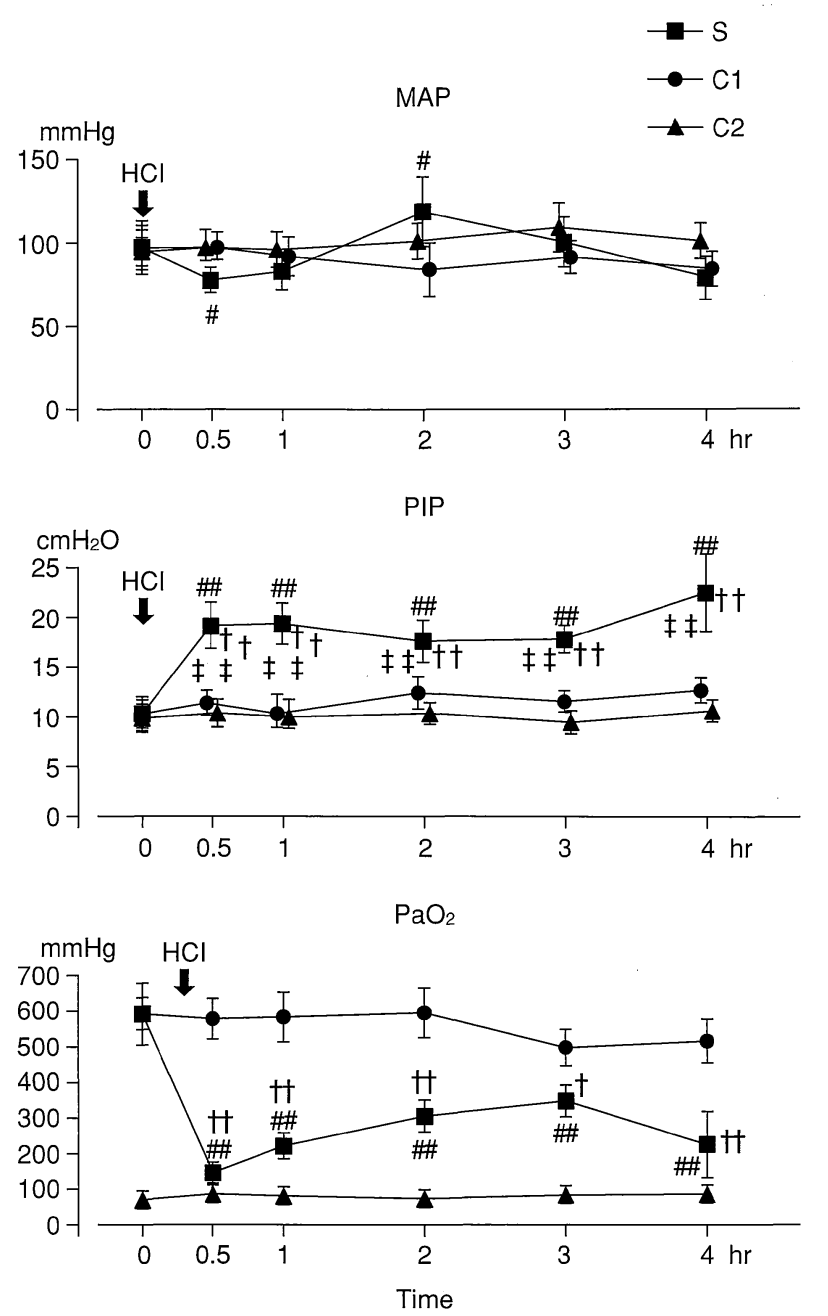

Fig. 1 Mean arterial pressure significantly decreased at $0.5 \mathrm{hr}$ and increased at $2 \mathrm{hr}$ after $\mathrm{HCl}$ administration in the study groups. Peak inspiratory pressure increased immediately after acid injection and stayed high for 4 hrs. $\mathrm{PaO}_{2}$ decreased within $0.5 \mathrm{hr}$ after acid instillation and improved gradually until $3 \mathrm{hr}$. MAP, mean arterial pressure; PIP, peak inspiratory pressure; S, study group; C1, control group 1. $\mathrm{C} 2$, control group 2 .

\#, $P<0.05$ vs $0 \mathrm{hr}$; \#, $P<0.01$ vs $0 \mathrm{hr} ;{ }^{\dagger}, P<0.05$ vs control group $1 ;{ }^{\dagger \dagger}, P<0.01$ vs control group $1 ;{ }^{\ddagger}, P<0.05$ vs control group $2 ;{ }^{\ddagger}, P<0.01$ vs control group 2 .

においては塩酸注入 30 分後に著明に上昇 $(P<0.01)$ し，2 時間後にやや回復を認めるも 4 時間後には再度 上昇した。C 群との比較でも $\mathrm{S}$ 群では塩酸注入後はい ずれも有意に高值であった。

c) $\mathrm{PaO}_{2}$

純酸素のみで行うたC1群，空気で行ったC2群では， $\mathrm{PaO}_{2}$ は各々経時的に一定の值を保った。一方 $\mathrm{S}$ 群では, $\mathrm{PaO}_{2}$ は塩酸注入後劇的に低下した。以後3時間目まで は軽度ながら回復を示したが，注入前に比較し有意に 低值であった。4時間目には再度低下した。これらは， 
また $100 \%$ 酸素を用いたC1群に比し有意に低い值を示 した。

2) $\mathrm{pH}, \mathrm{PaCO}_{2}$ (Fig. 2)

$\mathrm{pH}, \mathrm{PaCO}_{2}$ はともに，C1，C2両群において著変を 認めなかった。 $\mathrm{S}$ 群においては, pHは塩酸注入後低下 しその後一定となり，前值と比較し有意差はなかった。 一方, $\mathrm{PaCO}_{2}$ は塩酸注入後有意に上昇したが，3時間 目には高值ながらも有意差を認めなかった。しかし，4 時間目には有意に高值であった。C1群とS 群との比較 では，1，2 時間後に統計学的に有意差を認めた。

3) IL-8

a) BALF (Fig. 3)

BALF 中の IL-8の濃度は, S 群において経時的に増 加し 3 時間目に極值に達した。 4 時間目にはやや低下 するがなお有意に高值であった。一力，C1 群では C2 群に比較し 4 時間後の IL-8 は有意に高値であった。

b) 肺組織 (Fig. 4)

$\mathrm{S}$ 群の肺組織中の IL-8は, BALF とほぼ同様の傾向 を示した。3時間で極值をとり，4時間目には減少傾向 を認めるもののなお有意に高值であった。一方，4 時

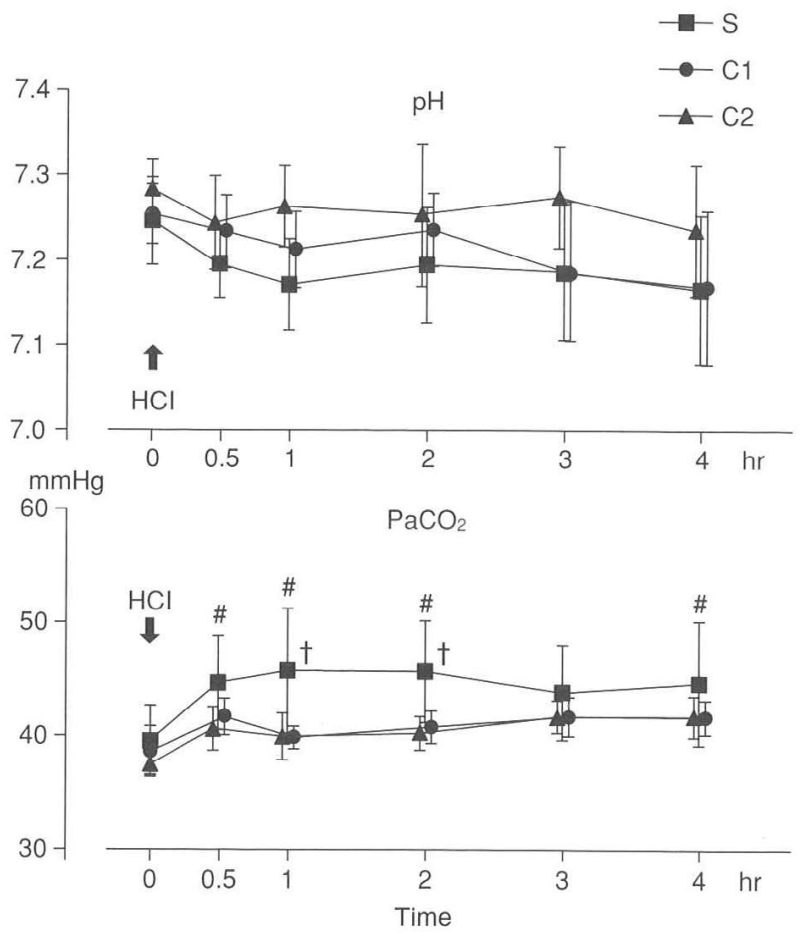

Fig. 2 There was no remarkable change of $\mathrm{pH}$ in any group. $\mathrm{PaCO}_{2}$ increased after acid instillation compared to baseline. $\mathrm{PaCO}_{2}$ in the study groups was higher than that in control group 1, at 1 and $2 \mathrm{hr}$. $\mathrm{S}$, study group; C1, control group 1; C2, control group 2.

\#, $P<0.05$ vs $0 \mathrm{hr} ;{ }^{\dagger}, P<0.05$ vs control group 1 .
間目の C1 群と S 群の肺組織中の IL-8 は, C2 群に比較 して有意に高值を示した。

c) 血液 (Fig. 5)

血液中の IL-8 は，S 群において塩酸注入 4 時間後の みに有意の上昇が認められた。4 時間後の群間を比較 すると，S 群は C1 群，C2 群に比して有意に高值を示 した。C1 群は増加を示したが，C2 群に比して有意差 はなかった。

\section{考察}

塩酸肺炎の病態に関する研究は古くから行われてお り 9). 10), その生理学的, 病理学的, および生化学的特 徵はかなり解明されている11)。そして，掹酸肺炎の重 症度は， $\mathrm{HCl} 0 \mathrm{pH}$ ，投与量，投与方法などにより異な ると考えられている。他の実験と比較して，本実験のHCl の $\mathrm{pH}$ は 1.5 と中等度であるが，投与量は $1.5 \mathrm{ml} \cdot \mathrm{kg}^{-1}$ とか なり多くなっている。同じ $\mathrm{pH}$ で，投与量 $0.2 \mathrm{ml} \cdot \mathrm{kg}^{-1}$ でもサイトカインの産生が誘導され，抗体によりブロッ クされるという知見がある12)。本実験の $\mathrm{S}$ 群では，塩 酸投与30分後に，低血圧，最高気道内圧の上昇，低酸

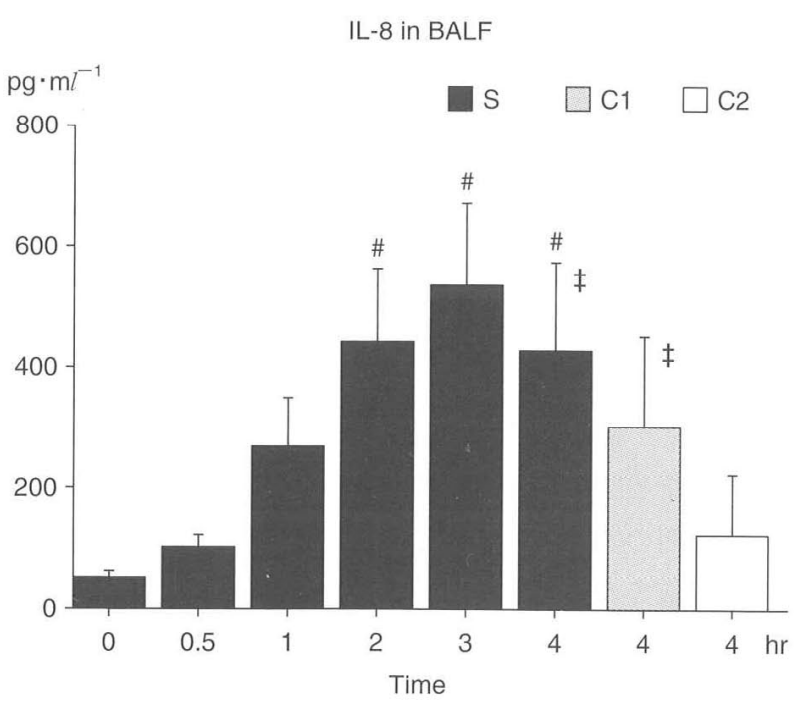

Fig. 3 Interleukin-8 (IL-8) in broncho-alveolar lavage fluid (BALF) significantly increased from $2 \mathrm{hr}$ after $\mathrm{HCl}$ instillation compared to baseline.

IL-8 at $4 \mathrm{hr}$ in the study group and in control group 1 was significantly increased compared to that in control group 2. S, study group; C1, control group 1; C2, control group 2.

${ }^{\#}, P<0.05$ vs 0 hr; ${ }^{\ddagger}, P<0.05$ vs control group 2. 
IL-8 in lung tissue

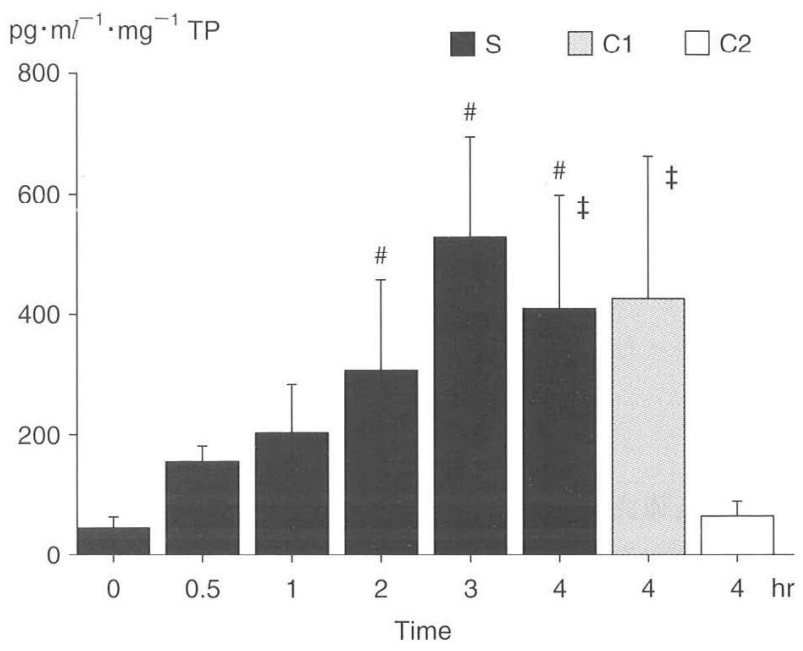

Fig. 4 Interleukin-8 (IL-8) in lung tissue showed the same time course with that in broncho-alveolar lavage fluid (BALF) . IL-8 in control group 1 was significantly higher than that in control group 2. IL-8 at $4 \mathrm{hr}$ in the study group was also significantly higher than that in control group 2.

$\mathrm{S}$, study group; $\mathrm{C} 1$, control group 1 ; $\mathrm{C} 2$, control group 2.

${ }^{\sharp}, P<0.05$ vs 0 hr; ${ }^{\ddagger}, P<0.05$ vs control group 2.

素血症, 高炭酸ガス血症を認め, これらは神経学的機 序が関与しているともいわれている10)。これらの反応 と同時に，塩酸によって刺激された肺胞マクロファー ジ，肺血管内皮細胞などから，補体13)，接着分子14)，口 イコトリエン $\mathrm{B}_{4}\left(\mathrm{LTB}_{4}\right)^{15)}$, TNF- $a^{12}$, IL-1b ${ }^{12}$, IL-86, などが産生される。続いて時間の経過とともに, 後期 の反応として3〜4時間後に，炎症反応が惹起される。 血管内皮と肺胞上皮の損傷, 好中球をはじめとする炎 症細胞の接着と血管外流出, プロテアーゼなどの蛋白 分解酵素や活性酸素の放出による組織の崩壊16), 肺胞 構造の破壞などが認められ, さらに全身への炎症の波 及へとつながる17) 18)。本実験に抒いて，4時間目の血 圧の低下, 最高気道内圧のさらなる上昇, $\mathrm{PaO}_{2}$ の再度 の低下などはこれらの機序が関与していると思われる。 この後期の炎症反心の中心的役割を果たしているのが 炎症細胞であるとすれば，これらを引きつける走化性 因子が病因として重要であり，また，治療の標的とし て十分に期待できるものと考える。しかしながら，IL-8 を拮抗することで炎症反応が抑制されることが示され ても, IL-8の時間的推移を検討した報告はない.

近年，炎症細胞を集積する作用をもったIL-8と構造 の類似した物質が発見されており, ケモカインと呼ば れている19)。なかでもラットに扔ける好中球の走化性 因子は, cytokine-induced neutrophil chemoattractants
IL-8 in the blood

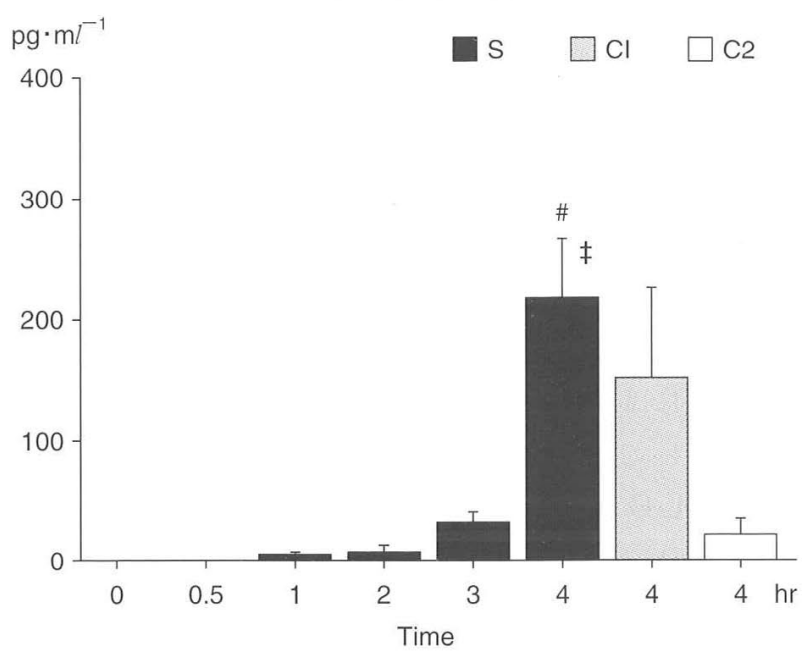

Fig. 5 Interleukin-8 (IL-8) appeared at $3 \mathrm{hr}$ in the blood and increased significantly after $4 \mathrm{hr}$. Neither IL8 in control group 1 nor that in control group 2 significantly increased.

S, study group; C1, control group 1; C2, control group 2.

${ }^{\#}, P<0.05$ vs 0 hr; ${ }^{\ddagger}, P<0.05$ vs control group 2 .

(CINC) と呼ばれている。CINCはさらにGRO/CINC, $\mathrm{GRO} / \mathrm{CINC}-2 \alpha, \mathrm{GRO} / \mathrm{CINC}-2 \beta, \mathrm{GRO} / \mathrm{CINC}-3$ の 4 種類が存在し, 今回測定したMIP-2は, GRO/CINC-3 に相当する20)。これらについて, 詳細にはいまだ不 明な点が多いが，実験的 ARDSモデルでは，MIP-2 (macrophage inflammatory protein) が好中球集積と 深い関わりがあることが示されている21)。

本実験の 100\%酸素で人工呼吸したC1 群において も，BALF，肺組織にIL-8の有意な上昇を認めた。肺 の酸素中毒にもIL-8が関与していることは以前より知 られており, 肺胞マクロファージが高濃度酸素に暴露 されてIL-8を産生することが確認されている22)。S 群 では，はじめから 100\%酸素を投与しているため，純 酸素によるIL-8の誘導が関与していることも否定でき ない。しかしながら，血中へ遊離した IL-8 は，100\% 酸素投与のC1群でより少なく, S群で多かった。抒そ らく，塩酸により alveolar-capillary barrier が障害を 受け，IL-8が血液へ遊離し，走化性を発揮したものと 思われる。

動物実験に抒いて，炎症細胞の走化性因子である IL-8 をモノクローナル抗体によりブロックし, 肺再灌流障 害の改善, エンドトキシンによる肺障害の是正, 免疫 複合体型系球体腎炎，エンドトキシン誘導性腹膜炎の 軽減などを来したとする報告は多い23)。また，IL-8受 
容体ノックアウトマウスでは，炎症誘導物質の腹腔内 投与による好中球浸潤は減少し好中球遊走能の低下が 示されている24)。一方, 臨床的にも, IL-8 が高值の $\mathrm{ARDS}^{25)}$ ，敗血症 ${ }^{26)}$, 多発外傷 ${ }^{1)}$, 頭部外傷 ${ }^{27)}$ 患者で 予後不良であることが示されている。特に本実験の主 題であるARDSでは，心不全による肺水腫よりも ARDSにおいて，さらに敗血症を伴うARDSにおいて， 肺水腫液中および血清中のIL-8が高值を示したことか ら，IL-8を標的とした治療に期待が寄せられている28)。 ところで，sepsisをはじめとする炎症疾患に対して， 抗TNF- $a$ 抗体による抗サイトカイン療法が, 動物実 験などでは良好な結果を得たが，多施設による臨床的 な検討においての有効性は否定された29)。一方，IL-8 はTNF- $a$ にも誘導を促進されることが知られている が, 他のサイトカインと比べて, 時期的に遅れて出現 することから，標的として捕らえやすいものと考える。 実際に，塩酸肺炎に対する抗IL-8抗体は前処置のみな らず，塩酸処置30分後でも十分に有効であった6)。肺 損傷の抑制のために抗IL-8抗体を投与するならば，血 中濃度の推移から見て, 血中に遊離し始める 3 時間以 内が望ましいと思わる。

侵襲下において, サイトカインは複雑なネットワー クをつくる。例えば，炎症免疫反応におけるTNF- $a$, IL-6，IL-1の生理作用は非常に似通っており，また，共 通のレセプターをもつサイトカインも多いため，一つ のサイトカインを抑えても，バックアップシステム， フェイルセイフ機構が働くと考えられている。そのた め，IL-8のみを標的としても，必ずしも完全には抑制 されない可能性はある。また，臨床の場においては，誤 嚥性肺炎が必ずしも, 重篤な肺損傷を起こすとは限ら ず，抗IL-8療法の適応，副作用など考慮すべきであろ う。しかしながら，他の動物実験でみられるごとく，抗 IL-8療法により，標的組織の炎症反応が確実に抑えら れるならば，予後は劇的に改善されると考えられ，将 来有力な治療法の一つになりうると思われる。

\section{文献}

1) Kolb DN, Waydhas C, Steppert CG, et al. Indicator of the post traumatic inflammatory response correlate with organ failure in patients with multiple injuries. J Trauma 1997; 42: 446-55.

2) Marie C, Fitting C, Cheval C, et al. Presence of high level of leukocyte-associated interleukin. Infect Immun 1997; 65: 865-71.

3) Headley AS, Tolley E, Meduri GU. Infections and the inflammatory response in acute respiratory distress syndrome. Chest 1997; 111: 1306-21.

4) Kanazawa M. Interleukin- 8 and adult respiratory distress syndrome. Intern Med 1997; 35: 835-6.

5) Yokoi K, Mukaida N, Harada A, et al. Prevention of endotoxemia-induced acute respiratory distress syndromelike lung injury in rabbits by a monoclonal antibody to IL8. Lab Invest 1997; 76: 375-84.

6) Folkesson HG, Matthay MA, Hebert CA, et al. Acid aspiration-induced lung injury in rabbits is mediated by interleukin-8-dependent mechanisms. J Clin Invest 1995; 96: 107-16.

7) Garber BG, Hebert PC, Yelle JD, et al. Adult respiratory distress syndrome: A systemic overview of incidence and risk factors. Crit Care Med 1996; 24: 687-95.

8) Nakagawa H, Komorita N, Shibata F, et al. Identification of cytokine-induced neutrophil chemoatractants (CINC), rat GRO/CINC- $2 \alpha$, and CINC- $2 \beta$ produced by granulation tissue in culture: Purification, complete amino acid sequence and characterization. Biochem. J 1994: 301: 54550.

9) Grimbert FA, Parker JC and Taylor AE. Increased pulmonary vascular permeability following acid aspiration. J Appl Physiol; Respirat Environ Exercise Physiol 1981; 51: 335-45.

10) Kennedy TP, Johnson KJ, Kunkel RG, et al. Acute acid aspiration lung injury in the rat: Biphasic pathogenesis. Anesth Analg 1989; 69: 87-92.

11) Britto J, Deming RH. Aspiration lung injury. New Horizon 1993; 1: 435-9.

12) Goldman G, Welbourn R, Kobzik L, et al. Tumor necrosis factor- $a$ mediates acid aspiration-induced systemic organ injury. Ann Surg 1990; 212: 513-20.

13) Rabinovici R, Neville LF, Abdullah F, et al. Aspirationinduced lung injury: Role of complement. Crit Care Med 1995; 23: 1405-11.

14) Nagase T, Ohga E, Sudo E, et al. Intercellular adhesion molecule-1 mediates acid aspiration-induced lung injury. A J Respir Crit Care Med 1996; 154: 504-10.

15) Goldman G, Welbourn R, Kobzik L, et al. Synergism between leukotriene $B_{4}$ and thromboxane $A_{2}$ in mediating acid aspiration injury. Surgery 1992; 111: 55-61.

16) Knight PR, Druskovich G, Tait AR, et al. The role of neutrophils, oxidants, and proteases in the pathogenesis of acid pulmonary injury. Anesthesiology 1992; 77: 772-8.

17) Goldman G, Welbourn R, Kobzik L, et al. Neutrophil adhesion receptor $\mathrm{CD} 18$ mediates remote but not localized acid aspiration injury. Surgery 1995; 117: 83-9.

18) John RC, Mizer LA, Kindt GC, et al. Acid aspiration-induced acute lung injury causes leukocyte-dependent systemic organ injury. J Appl Physiol 1993; 74: 1994-2003.

19) Baggiolini M, Dewald B, Moser B. Interleukin-8 and related chemotactic cytokines-CXC and CC chemokines. Adv. Immunol. 1994; 55: 97-109.

20) 原田明久, 松島綱治. IL-8. 笠倉新平編. サイトカイン. 東 京: 日本医学館, 1997; 180-6.

21) Driscoll K. Macrophage inflammatory proteins: Biology and role in pulmonary inflammation. Exp Lung Res 1994; 20: 473-90.

22) Deaton PR, McKellar CT, Culbreth R, et al. Hyperoxia stimulates interleukin-8 release from alveolar macrophages and U937 cells: Attenuation by dexamethasone. Am J Physiol 1994; 267: 187-92.

23) Harada A, Sekido N, Akahoshi T, et al. Essential involvement of interleukin-8 (IL-8) in acute inflammation. Leukocyte Biol 1994; 56: 559-64.

24) Cacalano G, Lee J, Kikly K, et al. Neutrophil and B cell expansion in mice that lack the murine IL-8 receptor homolog. Science 1994; 265: 682-4.

25) Ikuta N, Taniguchi H, Kondoh Y, et al. Sustained high 
levels of circulating interleukin- 8 are associated with a poor outcome in patients with adult respiratory distress syndrome. Intern Med 1996; 35: 855-60.

26) Damas P, Canivet JL, Groote DD, et al. Sepsis and serum cytokine concentrations. Crit Care Med 1997; 25: 405-12.

27) Kossmann T, Stahel PF, Lenzlinger PM, et al. Interleukin8 released into the cerebrospinal fluid after brain injury is associated with blood-brain barrier dysfunction and nerve growth factor production. J Cereb Blood Flow Metal
1997; 17: 280-9.

28) Miller EJ, Cohen AB, Matthay MA. Increased interleukin8 concentrations in the pulmonary edema fluid of patients with acute respiratory distress syndrome from sepsis. Crit Care Med 1996; 24: 1448-54.

29) Fisher CJ Jr, Agosti JM, Opal SM, et al. Treatment of septic shock with the tumor necrosis factor receptor: Fc fusion protein. N Engl J Med 1996; 334: 1697-702.

\section{Abstract}

Time course of interleukin-8 exudation in a hydrochloric acid-induced lung injury model

Kaneyuki Kawamae, Choichiro Tase, Masahiro Murakawa, Manabu Otsuki, Yukio Matsumoto, Jiro Shimada, Yukihiro Ikegami, Tsuyoshi Isosu

Department of Anesthesiology, Fukushima Medical University

1-Hikarigaoka, Fukushima-shi, 960-1295, Japan

Excessive interleukin-8 (IL-8) plays an important role as a key mediator in neutrophil-dependent inflammatory disease.

The purpose of this study was to elucidate the time course of IL-8 exudation from the local inflammatory tissue to systemic circulation using a hydrochloric acid $(\mathrm{HCl})$ injured lung model.

Fifty-six male Spraque-Dawley rats were mechanically ventilated after tracheostomy under ketamine and xylazine anesthesia. $1.5 \mathrm{ml} \cdot \mathrm{kg}^{-1}$ of $\mathrm{HCl}$ with $\mathrm{pH} 1.5$ was instilled through the endotracheal tube. The animals were randomly divided into 6 study groups according to the time at which they were sacrificed: before and 30 minutes, 1, 2, 3, and 4 hours after $\mathrm{HCl}$ injection. Two of the control groups did not receive $\mathrm{HCl}$. The first control group was ventilated with room air, and the second control group with pure oxygen for 4 hours. IL-8 concentrations in the blood, broncho-alveolar lavage fluid (BALF), and lung tissue were measured by enzyme-linked immuno-sorbent assay (ELISA).

IL-8 in lung tissue and in BALF significantly increased one hour after $\mathrm{HCl}$ instillation, while IL-8 in the blood significantly increased at 4 hours.

The release of IL- 8 into the blood was delayed for a few hours compared to the elevation of IL- 8 in lung tissue and in BALF.

Key words: (1) interleukin-8, (2) aspiration pneumonia, (3) hydrochloric acid lung injury, (4) cytokine

J Jpn Soc Intensive Care Med 1999; 6; $35 \sim 40$ 